Rethinking the Criminal Responsibility of Young People in England and Wales

Dr Raymond Arthur

School of Social Sciences \& Law, Teesside University, Middlesbrough, England 


\section{Rethinking the Criminal Responsibility of Young People in England and Wales}

\section{Abstract:}

In 2010 two boys, aged 10 years, were convicted of the attempted rape of an eight year old girl in England. This article will consider the question of when is it fair to hold young people criminally responsible and to subject them to the full rigours of a criminal trial. It examines the assumption that children today are maturing at an earlier age and argues that the law needs to recognise that children may not yet be developed enough to understand the wrongfulness of what they do. The article adopts a comparative approach by examining the position in Scotland, Ireland and Guernsey. The article also considers the implications of the United Nations Convention on the Rights of the Child and the reports of the UN Committee as well as examining American criminal jurisprudence.

\section{Introduction}

The conviction in England of two primary school boys for the attempted rape of an eight year old girl in 2010 once again case raises the issue of how old someone must be before they know they are committing a crime. The two boys were both aged 10 years old at the time of the offence and are the youngest males ever to be prosecuted for rape in England and Wales. They had been accused of repeatedly assaulting the girl in a block of flats, a lift and a bin shed before taking her to a field and raping her in October 2009. During cross-examination via video the girl admitted lying to her mother about the incident and admitted that no rape had occurred. There was no other useful medical evidence, DNA evidence or forensic evidence. Nevertheless based on the evidence of an eight year old girl the two boys were convicted of attempted rape. The presiding Judge, Mr Justice Saunders, highlighted the need for lessons to be learned from this case. This case raises the question of whether child perpetrators should be treated as adults. 
In England and Wales the age of criminal responsibility is set at 10 years. The current law thus assumes all children are sufficiently mature at this age to accept criminal responsibility for their behaviour. This article will consider the question of when is it fair to hold young people criminally responsible and to subject a young person to the rigours of a criminal trial. It will examine the assumption that children mature earlier than in the past and argue that the law needs to recognise that children may not yet be developed enough to understand the wrongfulness of what they do. I will argue that the low age of criminal responsibility in England and Wales runs the risk of children being prosecuted for crimes they are too immature to fully understand. A child of 10 years can know that they are doing something wrong but not appreciate it is criminally wrong and thus not form the requisite intent, or mens rea, to be criminally responsible.

\section{Principles of criminal liability}

The law, as a system of rules that guides and governs human interaction, is premised on the view that humans can understand and follow rules. The law's concept of a person is a practical, reasoning, rule-following being who understands the difference between right and wrong. Effective criminal law requires that citizens understand that certain conduct is prohibited, the nature of their conduct and the consequences for doing what the law prohibits. ${ }^{1}$ Thus criminal liability "should be imposed only on persons who are sufficiently aware of what they are doing, and of the consequences it may have, that they can fairly be said to have chosen the behaviour and its consequences". ${ }^{2}$ To be convicted of a criminal offence the defendant must have performed the actus reus and mens rea of the offence and

\footnotetext{
${ }^{1}$ S.J. Morse, 'Immaturity and irresponsibility', 88 Journal of Criminal Law and Criminology, (1997) 15-67.

${ }^{2}$ A. Ashworth, Principles of Criminal Law $4^{\text {th }}$ ed. (Oxford: Oxford University Press, 2003) p. 158.
} 
have no defence available to them. The actus reus is the prohibited conduct of a defendant. Mens rea is the mental element required by the definition of the crime. Mens rea has evolved into a requirement of positive culpability on the part of the defendant and is the means through which those who are thought to be deserving of punishment, because of their responsibility and their moral blameworthiness, are identified. Adults are presumed to be mature and to have developed their decision-making capacities and thus are held accountable for their behaviour. This article will consider whether it is appropriate to hold adults and young people as equally responsible and culpable for their behaviour.

When it comes to imposing criminal liability upon children, the law has traditionally recognised that children may lack the capacity to be mentally culpable. For example, the preNorman Laws of Ine dating from the eighth century suggest the age of 10 years as the age at which young people could be held criminally responsible for their actions, below 10 years of age they were considered to lack mens rea. Bracton's $13^{\text {th }}$ century treatise does not specify a minimum age of criminal responsibility but does refer to children being protected from the criminal law by virtue of their "harmlessness of intention", equating a child's "innocence of purpose" with a "lack of intention to harm". ${ }^{3}$ Young children were considered to lack the capacity to form culpable intent and thus could not be criminally responsible. By the $15^{\text {th }}$ century the pre-Norman age limits had been lowered to seven years of age. The Children Act 1908 created a separate and distinct system of justice for children based on the assumption that the basic competencies of young people and adults differ in fundamental ways that affect judgment. The 1908 Act represented the first time in England that a statute recognized that children were less responsible than adults for their actions and should not be subject to the

${ }^{3}$ H. de Bracton, 'De Legibus et Consuetudinibus Angliae', in G. Woodbine, ed., Four Thirteenth Century Law Tracts. (Yale: Yale University Press, 1910) pp. 143-159. 
full rigours of the criminal law. Subsequently section 50 of the Children and Young Persons Act 1933 raised the age of criminal responsibility from seven to eight years and the Children and Young Persons Act 1963 raised it to the current age of 10 years.

Although the minimum age of criminal responsibility in England and Wales is much lower than most other countries in Europe and many countries worldwide, traditionally the English youth justice system has not prosecuted young people once they have achieved the age of criminal responsibility, instead the presumption of doli incapax was invoked. The presumption of doli incapax meant that children would only be held criminally responsible if in addition to committing the actus reus and mens rea of a criminal offence, the prosecution could also prove, beyond all reasonable doubt, that when doing the act, the child knew that what they were doing was seriously wrong as opposed to being merely mischievous or naughty. Thus under English law a child below the age of 10 was considered doli incapax, a child between 10 and 14 was presumed doli incapax as at this age children were considered incapable of identifying right from wrong, and therefore lacked the criminal intent necessary for prosecution. To convict the child, the prosecution would need to rebut this presumption. The presumption of doli incapax ensured that the law treated people as fully responsible from 14 years of age while also reflecting a concern that "using criminal penalties to punish a child who does not appreciate the wrongfulness of his or her actions lacks moral justification". 4

${ }^{4}$ Penal Affairs Consortium The Doctrine of 'Doli Incapax'. (London: Penal Affairs Consortium, 1995) p.5. 
However attitudes towards children changed during the late twentieth century. In $C$ (A Minor) $v D P P^{5}$, which concerned the actions of a 12 year old boy who had been caught with a companion tampering with a motorbike, Mr Justice Laws in the High Court ruled that the presumption of doli incapax was "no longer part of the law of England". Laws J believed that the argument that a child of 12 years of age would not appreciate the moral obliquity of his actions was out of touch with today's society and contrary to common sense. Laws J argued that:

"whatever may have been the position in an earlier age, when there was no system of universal compulsory education ... this presumption at the present time is a serious disservice to our law". 6

The judgment of Laws $\mathrm{J}$ was subsequently overruled by the House of Lords ${ }^{7}$ on the grounds of legal propriety and the respective roles of the judiciary and parliament, rather than because of any judicial commitment to the merits of the presumption. Lord Lowry in the House of Lords stated that "the presumption has in recent years been the object of some logical and forceful criticisms" and that the presumption "is not, and never has been, completely logical". Lord Jauncey described the presumption as "an affront to common sense". Nevertheless the House of Lords ruled that abolishing the presumption of doli incapax was a significant change to the law and thus was a matter for parliament to consider rather than the judiciary. The arrival of the New Labour government in May 1997 signalled a willingness to accept the views of the High Court and the House of Lords. The White Paper No More Excuses recommended modernising "the archaic rule of doli incapax" as it was "contrary to common sense" which is "not in the interests of justice, or victims or of the young people

\footnotetext{
5 [1994] 3 All ER 190.

${ }^{6}$ [1994] 3 All ER 190, 196.

${ }^{7}$ [1995] 1 AC 1
} 
themselves". 8 The New Labour government, echoing the judgment of Laws J, asserted that the presumption might have been justified in an earlier era but that the existence of compulsory education from the age of five meant that children grew up much quicker, mentally and physically, and therefore knew right from wrong. ${ }^{9}$ Following this White Paper came the Crime and Disorder Act 1998, section 34 of which abolished the presumption of doli incapax. Section 34 thus means that a child aged 10 years of age is no longer presumed incapable of understanding the nature of criminal conduct and can be considered as legally responsible for their actions as an adult. Thus English law now "holds that a person is completely irresponsible on the day before his tenth birthday and fully responsible as soon as the jelly and ice-cream have been cleared away the following day". ${ }^{10}$ For Bandalli the abolition of doli incapax reflects a steady erosion of the special consideration afforded to children and is "symbolic of the state's limited vision in understanding children, the nature of childhood or the true meaning of an appropriate criminal law response". ${ }^{11}$ Similarly Fionda refers to the abolition of doli incapax as being part of an "almost stubborn blindness towards the incapacity of children." Its abolition reflects a complete refusal to recognise the nature of childhood and places greater emphasis on 'justice' and less emphasis on 'youth'. ${ }^{12}$ A brief survey of the age of criminal responsibility and the proportion of children that make up the prison population in European countries suggests that the lower the age of criminal responsibility, the larger the youth custodial population. Thus the countries with the lowest

\footnotetext{
${ }^{8}$ Home Office No more excuses: A new approach to tackling youth crime in England and Wales (London: The Stationery Office, 1997) para 4.4.

${ }^{9}$ Home Office, op. cit., para 8.

${ }^{10}$ A. Smith, 'Doli Incapax under threat', 53 Cambridge Law Journal (1994) 3: 426-428, 427.

${ }^{11}$ S. Bandalli, 'Children, responsibility and the new youth justice', in B. Goldson, ed., The New Youth Justice (Lyme Regis: Russell House, 2000) pp. 81-95, 94.

${ }^{12}$ J. Fionda, 'Case Commentary: The Age of Innocence? - The Concept Of Childhood In The Punishment Of Young Offenders' 10 Child and Family Law Quarterly (1998) 1: 77-87.
} 
ages of criminal responsibility - England and Wales, Turkey and Northern Ireland - fall within the top 6 highest youth prison populations. ${ }^{13}$

\section{Are children mature enough to understand the nature of criminal liability?}

As doli incapax is no longer available, any child aged 10 years or older is now held to understand the significance of their actions unless they are suffering from a recognised medical condition. The abolition of the presumption is partly based on the universal availability of education from the age of five years. However in $C$ (A Minor) $v$ DPP, Lord Lowry responded with the observation that "better formal education and earlier sophistication do not guarantee that the child will more readily distinguish right from wrong". ${ }^{14}$

Furthermore Cavadino observes that "in view of the association between truancy and offending ... many of the children concerned have in practice failed to benefit from universal compulsory education". ${ }^{15}$ To ensure that children understand the nature of criminal conduct, it is crucially important that young people attend school and the child's experience at school needs to be a positive one. However various studies have found a strong link between truancy and youth crime, both of which were found to have begun at the same time. The Offending, Crime and Justice Survey noted that truancy was a 'high risk' characteristic since $62 \%$ of truants in their study admitted to offending and/or anti-social behaviour. ${ }^{16}$ The findings from that Survey echo the findings of earlier research. For example, Graham and Bowling found that $67 \%$ of young males who had truanted from school admitted offences, whereas only $38 \%$

\footnotetext{
${ }^{13}$ Howard league for Penal Reform Punishing children: A survey of criminal responsibility and approaches across Europe (London: the Howard League, 2008), p.8.

14 ([1995] 1 AC 1, 39

15 P. Cavadino, 'Goodbye Doli - must we leave you?' 9 Child \& Family Law Quarterly (1997) 165-171, 167.

${ }^{16}$ J. Hales, C. Nevill, S. Pudney, S. Tipping, Longitudinal analysis of the Offending, Crime and Justice Survey 2003-06 (London: Home Office, 2009).
} 
of non-truants offended. ${ }^{17}$ Graham and Bowling concluded that for both males and females the odds of offending of those who truanted were more than three times greater than for those who had not truanted. The Youth Lifestyles survey 1998/99 found that the more persistent the truant the higher the offending rates. ${ }^{18}$ Among males aged 12 to 16 years $47 \%$ of those who had truanted more than once a month reported offending behaviour compared with $13 \%$ of those who had truanted less often and only $10 \%$ of non-truants. Clearly there is a reciprocal relationship between delinquency and truancy, truancy may be both a cause and a consequence of juvenile offending behaviour; therefore it is difficult to determine which causes which. Nonetheless the probability of committing offences rises considerably if truanting or excluded from school, especially permanently excluded. In 2005 the National Audit Office reported that the government had spent $£ 885$ million on anti-truancy initiatives in the period 1997-2004. ${ }^{19}$ Despite this increased spending, the rate of unauthorised absence remained the same. The most recent figures show the rate of unauthorised absence as higher than any annual figures since 1998 with 68,000 pupils absent from school every day. ${ }^{20}$

Not only must the child be attending school, but the child's experience of school and the extent to which they enjoy school, do well and achieve good results can be significant factors in preventing crime. Crosnoe et al. found that academic achievement was directly related to lower levels of delinquent behaviour. ${ }^{21}$ Studies conducted on violent behaviour and academic abilities have also found that juveniles with high grades were less likely to be involved in

\footnotetext{
${ }^{17}$ J. Graham, B. Bowling, Young People and Crime (London: Home Office, 1995).

${ }^{18}$ C. Flood-Page, S. Campbell, V. Harrington, J. Miller Youth Crime, Findings from the 1998/99 Youth Lifestyles Survey (London: Home Office, 2000).

${ }^{19}$ National Audit Office Improving School Attendance in England (Norwich: The Stationery Office, 2005).

${ }^{20}$ Department for Education Pupil Absence in Schools in England - Spring Term (London: Department for Education, 2010).

21 R. Crosnoe, K. Erickson, D. Glasgow, D. Stanford 'Protective functions of family relationships and school factors on the deviant behaviour of adolescent boys and girls: reducing the impact of risky friendships' 33 Youth and Society (2002) 515-544.
} 
violent behaviour and that violence increased as learning difficulties increased. ${ }^{22}$ Graham and Bowling found that detachment from school was a significant indicator of offending behaviour especially in young females. ${ }^{23}$ The Offending, Crime and Justice Survey asked respondents about their school environment and those who complained of poor teaching quality and a lack of clear rules, amongst other problems, also reported a 50\% offending rate. ${ }^{24}$ The Survey found that decreasing levels of school discipline increased the likelihood of an offending trajectory and drug use. Consequently it recommended that further consideration be given to enhancing schools' disciplinary policies.

Rather than using the availability of universal education as a justification for subjecting young people to the full rigours of the criminal justice system, greater attention needs to be paid to the links between the education system and the young person's offending behaviour. Universal education does not necessarily act as a guarantee that young people will understand the nature of criminal conduct, but may instead be part of the problem. Engaging young people in suitable education is fundamental to preventing them from offending in the future. However issues of education cannot be viewed in isolation from other aspects of a young person's life. The family has an important role to play in children's school adjustment, attendance and performance. Parents' involvement in school and monitoring of school performance lessens the likelihood of school failure and associated outcomes such as youth offending. ${ }^{25}$ In Wadsworth's study, comprising just over 5,000 persons born in 1946 it was found that the more interest parents took in their son's schooling, as measured by teachers,

\footnotetext{
${ }^{22}$ M. Beam, C. Chuansheng, E. Greenberger, 'The nature of adolescents' relationships with their "very important" nonparental adults', 30 American Journal of Community Psychology (2002) 305-325.

${ }^{23}$ J. Graham, B. Bowling, loc. cit.

${ }^{24}$ R. Hayward, C. Sharp Young people, crime and anti-social behaviour: findings from the 2003 Crime and Justice Survey (London: Home Office, 2005).

${ }^{25}$ C. A. Smith, S.B. Stern, S.B. 'Delinquency and Antisocial Behaviour. A review of family processes-intervention research’ Social Services Review (1997) 382, 403.
} 
the less likely it was that the son would become a young offender. ${ }^{26}$ Wadsworth's study was an investigation into the health, growth, development and criminal records of the children in the survey. At primary school $25 \%$ of boys whose parents were rated lowest became juvenile offenders compared with $7.5 \%$ of those rated highest. Even greater differences were found at the secondary school stage, $34.2 \%$ and $8 \%$ respectively. Graham and Bowling found that school truants usually had a poor relationship with one or both parents, family members in trouble with the law, low attachment to family and were poorly supervised in that their parents frequently did not know where their child was, whom they were with or what they were doing. ${ }^{27}$ Child sexual abuse also has a significant impact on children's education including social development, school behaviour, learning, bullying and truancy. ${ }^{28}$ Such children are more likely to truant from school and to engage in offending behaviour. Hart et al found that the risk factors for violent juvenile offending include parental conflict, learning difficulties and school failure. The protective factors assessed included parenting styles and academic achievement. ${ }^{29}$ If the government is serious about tackling juvenile offending behaviour then rather than subjecting young people to the rigours of the criminal justice system from the age of 10 , resources must be allocated to intervene positively in young people's lives to prevent them engaging in offending behaviour. Providing families and school with support may be an effective way of preventing socially alienated and vulnerable children from becoming offenders. Such an approach should help to keep children out of the criminal justice system, an already overcrowded system where vulnerable and needy children do not belong.

\footnotetext{
${ }^{26}$ M.E.J. Wadsworth, Roots of Delinquency (London: Martin Robertson, 1979).

${ }^{27}$ J. Graham, B. Bowling, loc. cit

${ }^{28}$ M. Nugent, A. Labram, L. McLoughlin, 'The effects of child sexual abuse on school life', 15 Educational and Child Psychology (1998) 4: 68-78.

${ }^{29}$ J.L. Hart, S.K. O'Toole, J.L. Price-Sharps, T.W. Shaffer, 'The risk and protective factors of violent juvenile offending', 5 Youth Violence and Juvenile Justice (2007) 4: 367-384:
} 
A recent study by the Youth Research Forum found that by the age of seven years, children are able to distinguish between right and wrong and seem to have some awareness of the criminal implications of their behaviour. ${ }^{30}$ This was an online quantitative survey based on a nationally representative sample of 750 7-16 year olds. However research which has examined the brain developments and cognitive functioning of adolescents has found that with respect to moral culpability, those parts of the brain that deal with judgement, impulsive behaviour and foresight develop in the twenties rather than the teen years. ${ }^{31}$ Neuroscience data using MRI images has found that there are developmental differences in the brain's biochemistry and anatomy that may limit adolescents' ability to perceive risks, control impulses, understand consequences and control emotions. ${ }^{32}$ The prefrontal lobe of the brain that mediates emotional impulses does not fully develop until the mid-twenties. The prefrontal cortex is involved in controlling goal directed behaviour, emotional processing and decision processing. Because the prefrontal lobe is not fully mature and is still developing during adolescence, teens are almost inevitably overly emotional and subject to wide mood swings, immature judgment, decreased risk perception and impaired future-time perspective. ${ }^{33}$ Also it has been found that $60 \%$ of children in the criminal justice system have significant speech, language or communication difficulties, ${ }^{34} 30 \%$ have a learning disability,

\footnotetext{
${ }^{30}$ G. Smith, N. Winkfield, The development of the moral compass: A study among children aged 7 to 16 in the UK, (Surrey, Youth Research Forum, 2011).

31 W. Di Mascio, 'Punishment has replaced juvenile redemption' Correctional Forum, September (2006) 2-3; R.C. Gur, 'Brain maturation and the execution of juveniles', University of Pennsylvania Gazette, January/February (2005) 103.

${ }^{32}$ F.J. Lexcen, D.N. Reppucci, 'Effects of Psychopathology on Adolescent medical DecisionMaking', 5 University of Chicago Law School Roundtable, (1998) 63: 63-106, 77.

${ }^{33}$ K.L. Modecki, 'Addressing gaps in the maturity and judgment literature: age differences and delinquency', 32 Law and Human Behaviour (2008) 78-91; J. Rutherford, 'Juvenile justice caught between The Exorcist and A Clockwork Orange', 51 De Paul Law Review (2002) 715-742, 727.

${ }^{34}$ K. Bryan, J. Freer, C. Furlong, 'Language and communication difficulties in juvenile offenders', 42 International Journal of Language and Communication Disorders (2007) 5: 505-520.
} 
$10 \%$ suffer from anxiety disorders and $5 \%$ have symptoms of psychosis. ${ }^{35}$ The association between speech and language disorders and behavioural difficulties is well established. ${ }^{36}$ Communication problems tend to be labelled as behaviour problems and difficulties in understanding make young people very vulnerable in relation to education. ${ }^{37}$ Offender treatment programmes are almost all language based. Communication problems will prevent young people from accessing these programmes and so increase their risk of re-offending. Speech and language therapy interventions with children can reduce the impact of their speech and language impairments consequently reducing their risk of developing behavioural and conduct problems and therefore reducing the risk of offending.

Although children may understand the difference between right and wrong from the age of seven years and may have some understanding of the criminal implications of their conduct, they do not yet possess the emotional maturity to control their impulsivity and appreciate the consequences of their actions. Children and young people are less mature than adults in terms of the judgment factors of responsibility, perspective and sensation seeking and thus experience difficulties in weighing and comparing consequences when making decisions and contemplating the meaning of long-range consequences that will be realized many years in the future. ${ }^{38}$ The English criminal justice system does not account for the evidence that

${ }^{35}$ Department of Health, Healthy children, safer communities (London: Department of Health, 2009).

${ }^{36}$ E. Humber, P.C. Snow, 'The language processing and production skills of juvenile offenders: a pilot investigation', 8 Psychiatry, Psychology and Law, (2001) 1: 1-11; B.J. Tomblin, X. Zhang, P. Buckwater, H. Catts, 'The association of reading disability, behavioural disorders and language impairment among second-grade children', 41 Journal of Child Psychology and Psychiatry, (2000) 4: 473-482.

${ }^{37}$ S.J. Hooper, J.E. Roberts, S.A. Zeisel, M. Poe, 'Core language predictors of behavioural functioning in early elementary school children: Concurrent and longitudinal findings', 29 Behavioral Disorders (2003) 1: 10-25.

${ }^{38}$ K.L. Modecki, loc. cit; J.L. Woolard, 'Capacity, Competence, and the Juvenile Defendant: Implications for Research and Policy', in B.L. Bottoms, M.B. Kovera, B.D. McAuliff, eds., 
children and young people differ in developmental maturity from adults and thus are less culpable than adults for their choices and behaviour. These cognitive difficulties also have implications for young peoples' ability to be competent defendants in adversarial atmospheres. ${ }^{39}$ Children and young people may have the capacity to perform competently and responsibly, but this does not mean that they are capable of exercising maturity of judgment. To apply the same standards to a 13 year old as an adult is to ignore large amounts of evidence about the life circumstances of children at that age. Youth offending behaviour represents a breakdown by the family, schools and child to teach and learn, respectively, proper conformity to lawful social order. Many youths entering the youth justice system have serious multiple problems in terms of their school achievement, psychological health and family life. Youth crime policies and interventions therefore need to avoid a narrow focus on the crime and take into account the family, social and contextual factors that are frequently associated with youth offending. Under the normal rules of criminal law, a defendant whose decision-making capacities are impaired, for example by mental illness, are deemed less blameworthy than typical offenders. The evidence supports the conclusion that children and adolescents are less capable decision-makers than adults in ways that are relevant to their criminal choices. ${ }^{40}$ If young people lack the capacity to make a meaningful choice and to control their impulses, should they be held criminally culpable for their behaviour?

These views are also reflected in judgments of English and US courts. The US Supreme Court decision in Roper $v$ Simmons $^{41}$ which declared the juvenile death penalty

Children, Social Sciences and the Law (Cambridge: Cambridge University Press, 2002) pp. 270-300.

${ }^{39}$ J.L. Woolard, loc. cit.

${ }^{40}$ E. Scott, L. Steinberg, 'Adolescent development and the regulation of youth crime', 18 The Future of Children (2008) 15-33, 20.

${ }^{41}$ (2005) 543 US 551 
unconstitutional also accepted and reaffirmed the presumption of the diminished responsibility of youth. The US Supreme Court ruled that young people's objective immaturity, vulnerability and comparative lack of control over their immediate surroundings renders them less culpable than adult criminals. In England, Lord Steyn, in the case of $R v G$ and $R^{42}$ emphasised that ignoring the special position of children in the criminal justice system is not acceptable in a modern civil society. In the same case Lord Bingham held that conviction of serious crime should depend on proof not simply that the defendant caused (by act or omission) an injurious result to another but that his state of mind was culpable when so acting. Bingham believed that although it was clearly blameworthy to take an obvious and significant risk of causing injury to another, it was not clearly blameworthy to do something involving a risk of injury to another if the accused genuinely did not perceive the risk. Such a person might fairly be accused of stupidity or lack of imagination, but neither of those failings should expose him to conviction of serious crime or risk of punishment. This case concerned two boys aged 11 and 12 years who went camping overnight without their parents' permission. During the course of this trip they threw lit newspapers under a plastic wheelie bin and caused $£ 1$ million of damage to a shop. The boys thought there was no risk of the fire spreading in the way it eventually did. Lord Bingham held that it was neither moral nor just to convict a young person on the strength of what someone else would have apprehended if the defendant himself had no such apprehension. As Lord Diplock stated, in the differing context of the partial defence of provocation to murder, "to require old heads on young shoulders is inconsistent with the law's compassion of human infirmity". ${ }^{4}$

\footnotetext{
42 [2003] UKHL 50, 53

${ }^{43}$ Camplin [1978] AC 705, 717
} 
The Law Commission for England and Wales also recently emphasised the view that desert based on moral fault is a necessary precondition for just punishment particularly in the context of young offenders. The Law Commission recommended that 'developmental immaturity' be incorporated into the defence of diminished responsibility, which is a partial defence to murder. ${ }^{44}$ The Law Commission recommended that it should be possible for the courts to consider whether the young person's developmental immaturity and cognitive limitations impairs their ability to stand trial for murder. The judgment that the actor is responsible has to be made first and this is why it is permissible to blame him or her for their actions, because a judgment has been made that he or she is a responsible actor. However this recommendation was not included in the Coroners and Justice Act 2009. The 2009 Act thus disregards the reality that terms such as 'intention' cannot and should not be applied without taking account of the large differences in capacity and judgment between adults and children. Moore argues that criminal liability should be avoided for a wrongful action if "at the moment of such action's performance, one did not have sufficient capacity or opportunity to make the choice to do otherwise". ${ }^{45}$ Moore views infancy as within the category of "status excuses' concerning “individuals who do not and cannot function well enough for us to confidently liken their actions and intentions to the actions and intention of sober, sane adults." Similarly Arenella asks "why should someone qualify as a moral agent if he lacks the capacity to deliberate about whether he should have acted differently?". 46 Until a young person is 16 years old they cannot consent to sexual relations or join the armed forces. The age at which you can buy cigarettes or alcohol or vote is 18 years. Thus the law recognises that these actions require a certain level of maturity and capacity and that children need

\footnotetext{
${ }^{44}$ Law Commission Murder, manslaughter and infanticide (London: The Stationery Office, 2006) para. 5.125.

${ }^{45}$ M.S. Moore, 'Choice, character and excuse', 7 Social Philosophy and Policy (1990) 2 219232, 229.

${ }^{46}$ P. Arenella, 'Character, choice and moral agency: the relevance of character to our moral culpability judgements', 7 Social Philosophy and Policy, (1990), 2: 59-83, 67.
} 
protection from the consequences of their immaturity in various areas of their lives. This should be equally appropriate for criminal responsibility, otherwise childhood becomes irrelevant to criminalisation. ${ }^{47}$

\section{Human rights obligations}

In $R v G$ and $R$ Lord Steyn argued that the criminal law was obliged to consider the mental incapactity of children in assessing their responsibility for criminal acts and drew special attention to the United Nations Convention on the Rights of the Child, Article 40.1 of which provides for the right of every child:

“... alleged as, accused of, or recognised as having infringed the penal law to be treated in a manner consistent with the promotion of the child's sense of dignity and worth .... and the desirability of promoting the child's reintegration in[to] society."

Article 40 of the Convention also requires each state to set a reasonable minimum age of criminal responsibility. The United Nations Standard Minimum Rules for the Administration of Juvenile Justice 1985 (the Beijing Rules) recommend that the minimum age of criminal responsibility should not be fixed at too low an age level, bearing in mind the facts of emotional, mental and intellectual maturity. The important consideration, as outlined in Rule 17 of the Beijing Rules, is whether a child, by virtue of his or her individual discernment and understanding, can be held responsible for their behaviour. The Commentary to the Beijing Rules stresses that there should be a close relationship between the age of criminal responsibility and the age at which young people acquire

47 S. Bandalli, 'Abolition of the presumption of doli incapax and the criminalisation of children', 37 Howard Journal of Criminal Justice (1998) 2: 114-123, 121. 
other social rights such as marital status and the right to vote. In line with this rule the UN Committee on the Rights of the Child has recommended the age of 12 years as the absolute minimum age of criminal responsibility. The UN Committee also strongly recommended that states parties set a minimum age of criminal responsibility that does not allow, by way of exception, the use of a lower age. ${ }^{48}$ In its report in 2002 the UN Committee expressed that it was "particularly concerned" about "the abolition of the principle of doli incapax" in England and Wales and recommended that the age of criminal responsibility should be raised considerably. ${ }^{49}$

The European Committee of Social Rights has also declared that the age of criminal responsibility in England is "manifestly too low" and accordingly was not in conformity with Article 17 of the European Social Charter which provides mothers and children with a right to social and economic protection. ${ }^{50}$ The European Social Charter is a Council of Europe treaty, signed in 1961, which guarantees social and economic human rights. The Council of Europe's Human Rights Commissioner has also frequently expressed concern at the low age of criminal responsibility in England. The Commissioner in 2005, Alvarez Gil-Robles, commented that he had "extreme difficulty in accepting that a child of 12 or 13 can be criminally culpable for his actions, in the same sense as an adult". ${ }^{51}$ While noting that the

${ }^{48}$ United Nations Committee on the Rights of the Child, General Comment No. 10: Children's Rights in Juvenile Justice (Geneva: United Nations Committee on the Rights of the Child, 2007), para. 32.

${ }^{49}$ United Nations Committee on the Rights of the Child, Consideration of Reports Submitted by State Parties under Article 44 of the Convention. Concluding observations: United Kingdom of Great Britain and Northern Ireland (Geneva: United Nations Committee on the Rights of the Child, 2002).

${ }^{50}$ European Committee of Social Rights, Conclusions XVII-2 (United Kingdom) Articles 7, 8, 11, 14, 17 and 18 of the Charter (Strasbourg: Council of Europe, 2005), para. 30.

${ }^{51}$ A. Gil-Robles, Report on his visit to the United Kingdom 4th-12th November 2004 for the attention of the Committee of Ministers and the Parliamentary Assembly (Strasbourg: Council of Europe, 2005), para. 105. 
European Convention on Human Rights does not require any age limit to be set before a child can be held criminally responsible, the Commissioner suggested that the age level in England should to be raised to bring it into line with other European countries. In 2006 the current Commissioner, Thomas Hammarberg, argued for an increase in the age of criminal responsibility across Europe with the aim of progressively reaching 18 years and recommended that innovative systems of responding to juvenile offenders below that age should be tried with a genuine focus on their education, reintegration and rehabilitation. ${ }^{52}$ Domestically, the House of Lords and House of Commons Joint Committee on Human Rights recommend that the age of criminal responsibility be increased to 12 years. ${ }^{53}$ The Joint Committee argued that unless evidence of the effectiveness of the present age of criminal responsibility in reducing crime and disorder can be convincingly presented, then it needs to be brought more in line with England's European neighbours. Such a recommendation would meet both the requirements of effective criminal justice and our duty under the UN Convention on the Rights of the Child to uphold children's human rights.

England's closest neighbours have taken steps to increasing their ages of criminal responsibility. In Scotland the age of criminal responsibility remains at eight years of age but the age at which children can be prosecuted in adult criminal courts has been raised to $12 .^{54}$ This change brings Scots law into line with jurisdictions across Europe and will mean that children between the age of eight and 12 years will instead be held to account for any offending behaviour through Children's Hearings. This system, which is respected internationally, addresses the needs and behaviour of children and young people who face

\footnotetext{
52 Council of Europe's Commissioner for Human Rights, The human rights dimension of juvenile justice, Thomas Hammarberg, CommDH/Speech (2006) 12.

53 Joint Committee on Human Rights, Tenth Report of Session 2002-2003 (London: The Stationery Office, 2003), para. 38.

54 section 52 Criminal Justice and Licensing (Scotland) Act 2010.
} 
serious problems in their lives. In Guernsey the Children Law 2008, effective since January 2010, significantly reformed arrangements for dealing with children in conflict with the law. The age of criminal responsibility has been raised to 12 years and the criminal court has been largely replaced by the Child Youth and Community Tribunal (CYCT), closely modelled on the Scottish Children's Hearing system. Unlike the Scottish system, however, which has a cut off at age 16, tribunals will deal with nearly all children below the age of 18 years. In the Republic of Ireland the Children Act 2001 raised the age of criminal responsibility in Ireland from seven to 12 years. This change means that children up to the age of 12 cannot be charged with a criminal offence. However the Criminal Justice Act 2006 allows for children as young as 10 years of age in Ireland to be charged with the offences of murder, rape and aggravated sexual assault. The Criminal Justice Act 2006 also abolished the rebuttable presumption of doli incapax which applied to any child between seven and 14 years. Children between 12 and 14, and those between 10 and 14 if they have been charged with a serious offence, no longer enjoy the presumption of doli incapax. For serious offences Ireland now shares with England one of the lowest ages of criminal responsibility in Europe.

There is evidence that public opinion would favour an approach to youth offending which recognises the particular vulnerability of young people. The Independent Commission on Youth Crime and Antisocial Behaviour found that public attitudes towards dealing with crime in Britain have hardened in the past 40 years and are among the most punitive to be found in any European country. ${ }^{55}$ 'Lenient sentencing' has been widely perceived as a cause of both youth and adult crime and appears to be a significant reason for the lack of

\footnotetext{
55 Independent Commission on Youth Crime and Antisocial Behaviour, Time for a fresh start. (London: The Police Foundation, 2010), p.23.
} 
confidence expressed in the youth justice system. ${ }^{56}$ However the Commission found that public views on youth crime are more complex than they appear. When participants in surveys have been given in-depth information about real cases and asked to select an appropriate sentence, their choice of sanction has turned out to be either similar or more lenient than the sentence that was actually imposed by a court. ${ }^{57}$ Although abstract questions about offenders and offending may elicit an immediate, punitive response, people tend to be more thoughtful and fair-minded when exposed to the facts and background of particular cases. ${ }^{58}$ More generally there are indications that the public express less punitive views towards young offenders than adults. Attitude surveys show agreement that youth and immaturity can be mitigating factors, especially if the offence did not involve weapons or violence. 'Deliberative' surveys, where the participants take a view on specific cases after learning about the background circumstances reveal an approach to sentencing that is even more temperate. For example, knowing that a young person is remorseful and has taken reparative steps to make good some of the harm their behaviour has caused to a victim can have a powerful influence in reducing demands for custodial sentences. ${ }^{59}$ A ComRes poll launched in March 2011 and conducted on behalf of the Transition to Adulthood (T2A) Alliance found that a majority of both the public (69\%) and members of parliament (81\%) believed that emotional and psychological maturity should be taken into account by the courts when dealing with a young person who breaks the law. Similarly, US research has found that the public may be more receptive to

\footnotetext{
${ }^{56}$ T. Jones, 'Public Opinion, Politics and the Response to Youth Crime', in D.J. Smith, ed., A New Response to Youth Crime (Cullompton: Willan, 2010); B. Duffy, R. Wake, T. Burrows, P. Bremner, Closing the Gaps. Crime \& Public Perceptions (London: Ipsos-MORI, 2008).

${ }^{57}$ M. Hough, A. Park, 'How Malleable are Attitudes to Crime and Punishment? Findings from a British Deliberative Poll', in J. Roberts, M. Hough, eds., Changing Attitudes to Punishment: Public Opinion, Crime and Justice (Cullopmton: Willan, 2002) pp. 163-184.

${ }^{58}$ T. Jones, op. cit.

59 J. Roberts, M. Hough, 'Sentencing Young Offenders: Public Opinion in England and Wales', 5 Criminal Justice (2005) 3: 211-232.
} 
differential treatment of youth and to more rehabilitative rather than punitive policies. Scott et al. in their study found little support for trying young people as adults or for treating young offenders as adults. ${ }^{60} \mathrm{~A}$ study conducted by the MacArthur foundation found that a majority of the public supports rehabilitation over incarceration and is willing to pay an additional $20 \%$ in taxes to provide rehabilitative services to young offenders. ${ }^{61}$ The Justice Policy Institute found that "what the public wants ... are rational and effective juvenile justice reforms that treat young people in developmentally appropriate ways". ${ }^{62}$

\section{Conclusion}

The Prison Reform Trust reported that many who work in the field of youth justice are convinced that the adversarial court system of England and Wales is inappropriate as a means of addressing the wrong doing of children. ${ }^{63}$ Young defendants often do not understand legal proceedings or the language used by lawyers, they report feeling intimidated and isolated in court and may not receive a proper explanation of what has happened until after a hearing is over. $^{64}$ They also feel frustration that the courts seem rarely to understand the context in which their offences were committed, including the pressures facing them.

\footnotetext{
${ }^{60}$ E. S. Scott, D.N. Reppucci, J. Antonishak, J.T. De Gennaro, 'Public attitudes about the culpability and punishment of young offenders', 24 Behavioural Sciences \& the Law (2006) 6: 815-832.

${ }^{61}$ A. R. Piquero, L. Steinberg, 'Public preferences for rehabilitation versus incarceration of juvenile offenders', 38 Journal of Criminal Justice (2010) 1-6.

${ }^{62}$ Juvenile Policy Institute, The accelerating pace of juvenile justice reform (Washington: Justice Policy Institute, 2007).

${ }^{63}$ J. Jacobson, J. Talbot, Vulnerable Defendants in the Criminal Courts: a review of provision for adults and children. (London: Prison Reform Trust, 2009).

${ }^{64}$ N. Hazel, A. Hagell, L. Brazier, Young Offenders' Perceptions of their Experiences in the Criminal Justice System (London: Policy Research Bureau, 2002), p.23.
} 
The Privy Council stated in a different context in the case of Kunnath $v$ the State ${ }^{65}$ that it was an essential principle of the criminal law that a criminal trial should be conducted in the presence of the defendant and that the defendant "should be able to understand the proceedings and decide what witnesses he wishes to call, whether or not to give evidence and if so, upon what matters relevant to the case against him." In $V . v$ the United Kingdom and T. $v$ the United Kingdom ${ }^{66}$ the European Court of Human Rights determined that the trial of a child aged as young as 11 does not in itself give rise to a breach of the Convention, as long as effective participation is ensured. This requires that the child is dealt with in a manner which takes full account of his or her age, level of maturity and intellectual and emotional capacities, and that steps are taken to promote his or her ability to understand and participate. In S.C. v United Kingdom ${ }^{67}$ the European Court of Human Rights held that when a child faces prosecution there is a risk that he will be unable to participate effectively because of his young age and limited intellectual capacity and stated that 'effective participation' in this context pre-supposes that the accused has a broad understanding of the nature of the trial process and of what is at stake for him, including the significance of any penalty that may be imposed. The young defendant should be able to follow what is said by prosecution witnesses and to explain his version of events, point out any statements with which he disagrees and make his lawyers aware of any facts which should be put forward in his defence: Young people must have a rational understanding of court proceedings in order for them to be able to participate meaningfully in any court case involving them. If young people are not sufficiently mature and competent to understand the process of a trial in a criminal court, can they be held criminally culpable for their behaviour?

\footnotetext{
65 [1993] 4 All ER 30.

${ }^{66}$ [2000] 30 EHRR 121.

${ }^{67}$ [2004] 40 EHRR 121.
} 
Furthermore Newbury's study found that the current youth justice system's restorative justice approaches do not work for the very young offender in that they are complex, processoriented and laden with language, and requirements for conference-style meetings, beyond the grasp of most 10, 11 or 12 year olds. The complex terminology (reparation, contract, etc) and the meeting-based, rather than activity-based, approach is too demanding for the majority of the youngest offenders. ${ }^{68}$

The age of criminal responsibility in England and Wales should be reviewed with a view to raising it at least to the UN Committee on the Rights of the Child recommended minimum of 12 years with the aim of progressively reaching 18 years as recommended by the Council of Europe's Human Rights Commissioner. Meanwhile the presumption of doli incapax should be re-established, and children who commit offences should be dealt with through a welfarebased approach. The adoption of a welfare approach to child offending does not imply that the harms caused by youth offending should be tolerated, but means ensuring that all children who are alleged to have offended have access to the range of health and social care services they require whether they are formally prosecuted or not. And with respect to those who are prosecuted, it entails recognising fully the range of difficulties that they are likely to face throughout the court process, and taking steps to address them.

${ }^{68}$ A. Newbury, 'Very young offenders and the criminal justice system: are we asking the right questions?' 23 Child and Family Law Quarterly (2011) 1: 94-112. 